\title{
Attitudes Towards Using Digital Technologies in Education as an Important Factor in Developing Digital Competence: The Case of Slovenian Student Teachers
}

\author{
https://doi.org/10.3991/ijet.v16i14.22649 \\ Tina Štemberger ${ }^{\bowtie}$, Sonja Čotar Konrad \\ University of Primorska, Koper, Slovenia \\ tina.stemberger@upr.si
}

\begin{abstract}
The purpose of the study was to determine what attitudes specifically Slovenian student teachers hold towards using digital technologies in education, their self-reported proficiency in using digital technologies in education and to what extent their attitudes towards using digital technologies in education predict their self-reported proficiency in using digital technologies. We measured the attitudes towards using digital technologies in education through four dimensions: Teaching and learning, Assessment and critical thinking, Empowering learners and Facilitating learner's digital competence. Selfreported proficiency in using digital technology was measured on four groups of digital technologies: Digital resources, Communication tools, Digital tools and Online learning tools. The results show that Slovenian student teachers predominantly hold positive attitudes towards using digital technologies in education, but they assess themselves as low-level users. Also, the student teachers' attitudes towards using digital technologies in education were proved as an important predictor of their level of proficiency in using digital technologies.
\end{abstract}

Keywords - Digital technologies, student teachers' attitude, teachers

\section{Introduction}

Teacher digital competence is a relative term with respect to time and context, with the given national curriculum always an essential part of this context, as it outlines what competence is considered relevant for teachers [1]. [2] proposes understanding that digital competence, along with instrumental skills, encompasses the ability to evaluate and use information critically, and to comprehend the role of technology and its development in social, political, and economic contexts. [3] further defines digital competence as skills, knowledge, creativity, and attitudes which teachers need, to manage the demands of the knowledge society. This definition was later adopted in other research in the field (e.g. [4], [5]) that all agrees that the main dimensions of digital competence are knowledge, attitude and skills. In particular, [5] emphasise the importance of attitude, since attitude is essential in constructing a specific mindset to adapt to new requirements. Additionally, [6] show that teachers have a prominent role 
in building digital competence in children and are also [7] responsible to empower students in this field.

In general, teachers today face rapidly changing demands and broader, more sophisticated sets of competences, including a continuously higher interest in empowering teachers with the necessary competences to fully exploit the potential of digital technologies, to enhance teaching and learning and adequately prepare students for life and work in a digital society [8, 9]. Numerous frameworks, self-assessment tools and training programmes have been developed to describe the facets of digital competence for teachers, and to help them assess their competence, identify their training needs and offer targeted training $[10,11,5,12,13]$. Based on an analysis and comparison of various instruments, the European Commission presented a common European Framework for the Digital Competence of Educators (DigCompEdu), presented in Figure 1 [9]. The DigCompEdu was the basis for our study's questionnaire on attitudes towards using digital technologies ${ }^{1}$ in education.

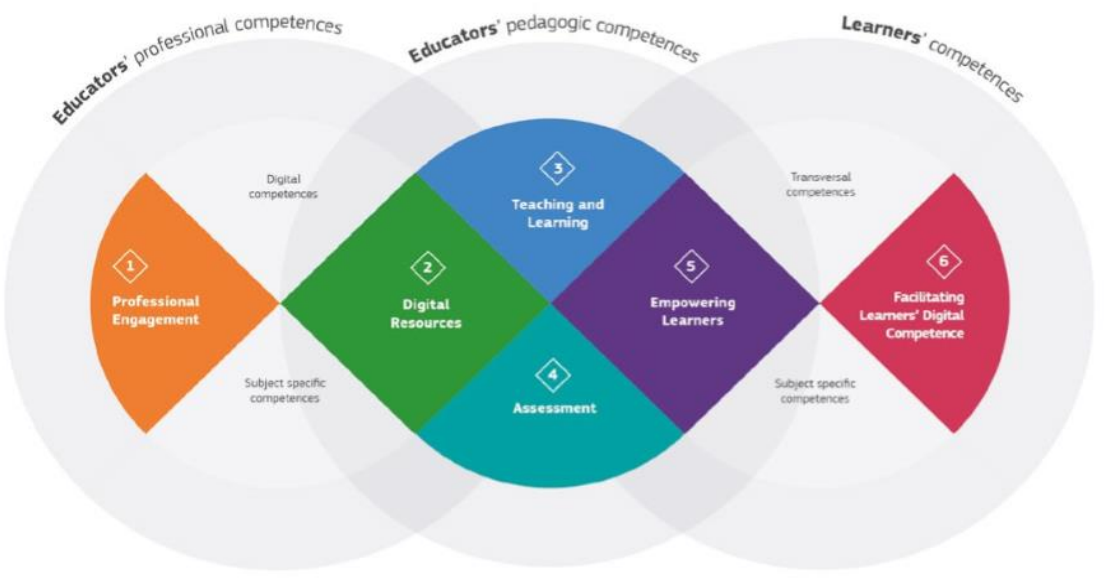

Fig. 1. DigCompEdu areas and scope [9].

The DigCompEdu framework encompasses six different areas of educators' digital competence, each focusing on different aspects of educators' professional activities. Its core is comprised of pedagogical competences that educators need in order to foster efficient, inclusive and innovative teaching and strategies. Specifically, this pedagogical core involves sourcing, creating and sharing digital resources; managing and orchestrating the use of digital technologies in teaching and learning; using digital technologies and strategies to enhance assessment; and using digital technologies to enhance inclusion, personalisation and learners' active engagement, that is, empower-

${ }^{1}$ We embraced the term digital technologies as an umbrella term for digital resources and devices comprising any kind of digital input: software, hardware or digital content [9]. 
ing learners. Prior to developing pedagogical competence, however, educators need to be professionally engaged in using digital technologies for communication, collaboration and professional development.

Facilitating learners' digital competence refers to supporting learner-centred pedagogic strategies, and learners' active involvement in the learning process and their ownership of it [9].

\section{Digital Competence in Teacher Education}

Various European documents (e.g. $[14,15]$ recognize the key role of teacher competence in assuring education quality in the $21^{\text {st }}$ century. Teachers also need high levels of digital competence, which certainly adds to the complexities within teacher education [16, 17, 18]. As explained in [17], digital competence is more complex in the teaching profession, as opposed to other occupations, as there are two levels to their digital competence. The first relates to teachers' ability to use technology in a seamless way, to encourage students to mirror such personal use, while the second is pedagogical in its focus, as teachers must simultaneously "continually make pedagogic didactic judgements which focus on how digital technologies can expand the learning possibilities for pupils in subjects" [16] As a result, digital competence is recognized as one of the key elements of teacher education in many countries [19, 20, 21]. Consequently, various models of digital competence in teacher education have begun to emerge.

The Digital Competence in Teacher Education (PEAT) model, developed in [22], engages technical and pedagogical competences and ethical and attitudinal dimensions. Positive attitudes and openness to new technologies are not explicitly mentioned in any other frameworks but given the importance of perceived digital competence as a predictor of teachers' technology use, openness and positive attitudes towards digital technology use in education appear to be important dimensions of teachers' digital competence $[10,11,5,13,23]$. Developing positive attitudes towards using digital technologies in education should thus be one of the key priorities in progressing and carrying out teacher education programmes. 


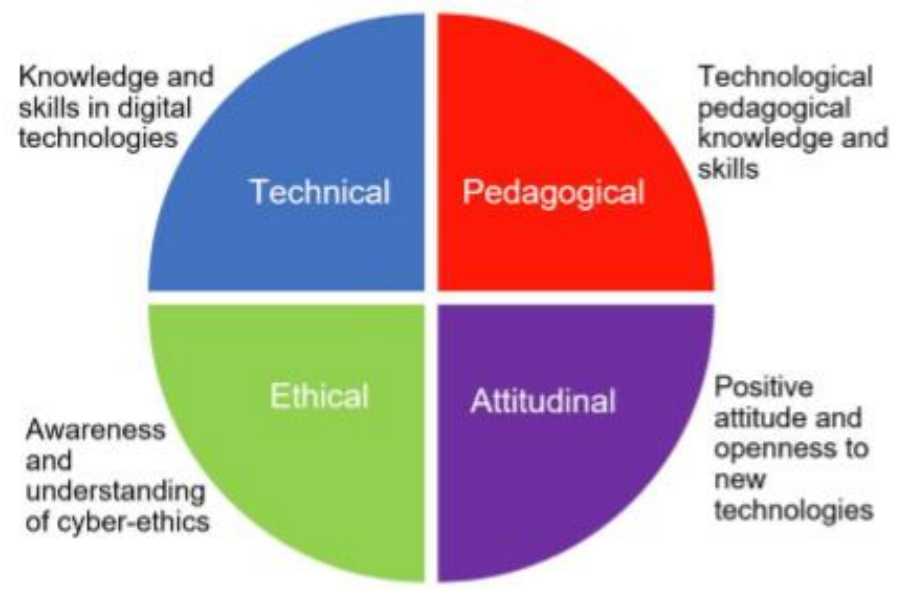

Fig. 2. The PEAT model [22].

Research has shown that student teachers express positive attitudes towards digital technology use in education but are still not completely devoted in their support of technology $[24,19,24,25,26]$. Research also indicates that technology is often under-used by student teachers or novice teachers [27, 19, 28, 29, 30]. However, according to [22], the use of digital technologies among student teachers and novice teachers is still under-researched.

\section{Teacher Education in Slovenia}

In Slovenia, as in all European countries, the teaching profession is a regulated profession, which means that minimum qualifications are required to become a teacher [31]. According to the [32], [33] and [34], primary and secondary school teachers need to obtain a master's level of formal education; they can choose different educational paths to acquire the appropriate qualification. Future teachers can engage in initial teacher programmes and concurrent programmes that are usually offered by faculties of education and certain other multidisciplinary faculties (e.g. the Faculty of Arts, the Faculty of Mathematics, etc.). The higher education institutions that deliver initial teacher education usually have a great deal of autonomy in developing programme content [31].

Until recently, initial teacher education (ITE) programmes in Slovenia were prepared based on the Standards for Accreditation for ITE [35]. These standards specified the scope of pedagogical training within the ITE study programme. ITE programmes had to include pedagogical-psychological knowledge, which encompassed psychology, pedagogics, didactics, andragogy, educational research, and humanities and social sciences knowledge, which included philosophy, sociology and anthropology, as well as courses or special didactics related to the study of the primary discipline and school placement. However, the Standards were omitted in 2018. Currently, 
there are no valid standards on which new ITE programmes must be based. In the process of accreditation, the programmes are evaluated by a group of at least three trained and licenced experts assigned by the Slovenian Quality Assurance Agency for Higher Education (SQAA). For the purposes of accreditation, the composition and content of the study programme and the concept of its delivery are examined [36]. Prior to final accreditation, the SQAA acquires the opinion of the Ministry of Education, Science and Sport [31]. Each study programme consists of various elements, including the aims of the programme, the proposed competencies and the courses that would be taught within the study program. The courses are also weighed in terms of the ECTS (European Credit Transfer and Accumulation System), which represents learning based on defined outcomes and their associated workload. Typically, 60 ECTS credits are the equivalent of a full year of study, and the credits are broken down into several smaller units. The first cycle (undergraduate) degree usually consists of either 180 or 240 ECTS credits, and the second cycle (postgraduate) equals to 90 or 120 ECTS credits [37].

The report Digital Education at School in Europe [31] categorizes Slovenia in a group of countries in which teacher digital competence is included in general teacher competence frameworks (as opposed to countries in which there is a specific digital competence framework). In addition, Slovenia is also included in a group of countries where teacher-specific digital competences are not subject to the regulations for ITE issued by top-level authorities, which results higher education institutions delivering ITE are autonomous in deciding on including digital competence as a part of ITE curriculum. However, developing teacher digital competence was the aim of several projects that were issued and controlled on a national level, by the Slovenian Ministry of education, science and sports.

The starting point of systematic implementation of ICT in education was the project Computer Literacy in 1994, which was followed by some other (e.g. e-schooling, e-competent teacher, e- school bag, smart boards, e-students books, etc.) attempts to make progress in including ICT in education. It has been reported that in the last 30 years the goal of empowering teachers with basic digital skills has progressed to empowering teachers for pedagogical (didactic) use of ICT. The analysis [38] indicates that Slovenian teachers often participate in various short-term (one or two days) inservice programmes aimed to acquire competence for didactic use of ICT. However, it has been established that these programmes do not respond to the needs sufficiently and new measures aiming at developing teachers' digital competences have been taken. The Ministry of Education, Science and Sports [38] proposed six key digital competences for teachers to be developed:

Ability to communicate and cooperate (with other teachers, parents, students, etc.) at a distance;

- Ability to search, collect, process and critically evaluate data and information

- Safe use of digital technologies and following legal and ethical principles in using and publishing information

- Production, creating, updating and publication of materials

- The ability to plan, implement and evaluate lessons by using ICT 
Recognising the fact that teachers need to develop their digital competence already within ITE, the Ministry started the project "Developing innovative methods of teaching and learning in ITE programmes" in 2017. The project aimed at empowering the prospective teachers (student teachers) with the basic knowledge of didactic use of ICT. The first step in delivering the project was the analysis of the student teachers' attitude towards using digital technologies in education and their self-reported proficiency in using digital technologies. A part of this analysis is presented in the present paper.

\section{$4 \quad$ Purpose of the Study}

The first aim of the present study was to determine what attitudes Slovenian student teachers hold towards using digital technologies in education. We first analysed the four dimensions of student teachers' attitudes towards digital technologies in education: (i) Teaching and learning, (ii) Assessment and critical thinking, (iii) Empowering learners and (iv) Facilitating learners' digital competence. The second aim referred to the student teachers' self-reported proficiency in using digital technologies, as divided into four groups: (i) Digital resources, (ii) Communication tools, (iii) Digital tools and (iv) Online learning tools. Finally, we wanted to establish whether and how attitudes towards using digital technologies in education predicts self-reported proficiency in using digital technologies in education.

\section{$5 \quad$ Methodology}

\subsection{Participants}

The study included 261 student teachers who were randomly chosen, so as to include participants from all over Slovenia. Of them, 179 (69.1\%) were first Bolognian cycle students, and $80(30.9 \%)$ were second Bolognian cycle students. Among all participants, $150(57.5 \%)$ were full-time students and $111(42.5 \%)$ were part-time students, while 92 (35.7\%) were first-year students, 85 (32. 9\%) second-year students, $46(17.8 \%)$ third-year students, $20(8.8 \%)$ fourth-year students and $15(5.8 \%)$ fifthyear students. Researchers followed all the ethical principles. They contacted the potential respondents via e-mail addresses which were previously gathered by the University and the students had consented that the addresses are allowed to use by the lecturers. The participation in the study was voluntary.

\subsection{Instrument and procedure}

We gathered our data in 2018 using the "student teachers' attitudes towards using digital technologies in education scale" from [8] which measures four dimensions: (i) Teaching and learning, (ii) Assessment and critical thinking, (iii) Empowering learners and (iv) Facilitating learners' digital competence. Teaching and learning consists 
of 8 statements, Assessment and critical thinking 4 statements, Empowering learners 7 statements and Facilitating learner's digital competence 5 statements. Participants were asked to respond to these statements on a 4-point scale ( $1=$ I completely disagree, 2 = I disagree, $3=\mathrm{I}$ agree, $4=\mathrm{I}$ completely agree). A Cronbach's alpha test proved the dimension scales to be reliable $\left(\alpha_{\mathrm{TL}}=0.859, \alpha_{\mathrm{A}}=0.814, \alpha_{\mathrm{E}}=0.714, \alpha_{\mathrm{F}}=\right.$ 0.868 ). The participants were also asked to assess their own proficiency in using digital technologies, with the technologies divided into four groups: (i) Communication tools, (ii) Digital resources, (iii) Digital tools and (iv) Online learning tools. The first three groups included 3 items each, while the last group included 9 items. Respondents assessed their level of proficiency using the listed tools on a 5-point scale. In addition to the scales, participants were asked to report the year of their study $\left(1^{\text {st }}, 2^{\text {nd }}\right.$, $\left.3^{\text {rd }}, 4^{\text {th }}, 5^{\text {th }}\right)$, their Bolognian cycle level $\left(1^{\text {st }}\right.$ cycle, $2^{\text {nd }}$ cycle $)$ and their mode of study (full-time, part-time).

\subsection{Data analysis}

Based on the model provided by [8] we first, by computing individual items. We formulated four dimensions of attitude: (i) Teaching and learning, (ii) Assessment and critical thinking, (iii) Empowering learners and (iv) Facilitating learners' digital competence, next computed the individual digital tools into four groups of digital technologies. For both the attitudes towards using digital technologies in education and the self-reported proficiency in using digital technologies, we performed descriptive statistics and later multiple regressions using a Stepwise method, with the aim to establish whether (dimensions of) attitudes towards using digital technologies are a predictor of self-reported proficiency level in using digital technologies.

\section{$6 \quad$ Results}

\subsection{Attitudes towards using digital technologies in education}

As shown in Table 1, the student teachers in general have positive attitudes towards using digital technologies in education. The highest value $(\mathrm{M}=3.10, \mathrm{SD}=$ 0.39 ) showing the most positive attitudes, is for dimension Teaching and learning, followed by Facilitating learners' digital competence $(\mathrm{M}=2.82, \mathrm{SD}=0.48)$. Additionally, the average values for Assessment $(\mathrm{M}=2.50, \mathrm{SD}=0.55)$ and Empowering learners $(M=2.69, \mathrm{SD}=0.45)$ indicate predominantly positive attitudes towards using digital technologies for assessment. 
Table 1. Descriptive statistics of the four dimensions of attitude

\begin{tabular}{|l|c|c|c|c|c|}
\hline \multicolumn{1}{|c|}{ Dimensions } & n & M & SD & Skew & Kurt \\
\hline Teaching and learning & 233 & 3.10 & .39 & .116 & .512 \\
\hline Assessment & 217 & 2.50 & .55 & -.204 & .833 \\
\hline Empowering learners & 235 & 2.69 & .45 & .265 & .795 \\
\hline Facilitating learners' digital competence & 218 & 2.82 & .48 & -.122 & .995 \\
\hline
\end{tabular}

Legend: $\mathrm{n}=$ numerus, $\mathrm{M}=$ mean, $\mathrm{SD}=$ standard deviation, Skew = skewness, Kurt $=$ kurtosis.

\subsection{Self-reported proficiency in using digital technology}

The results in Table 2 show that the student teachers on average report themselves to be basic-level users of Communication tools $(\mathrm{M}=3.22, \mathrm{SD}=0.70)$ and Digital resources $(M=3.22, S D=0.75)$. Their self-reported proficiency in Digital tools $(M=$ $2.36, \mathrm{SD}=0.68)$ and Online learning tools $(\mathrm{M}=2.35, \mathrm{SD}=0.72)$ is lower, showing the student teachers consider themselves to be basic-level users or even less, where they know the tools but do not use them.

Table 2. Descriptive statistics for four digital technology groups.

\begin{tabular}{|l|c|c|c|c|c|}
\hline Digital technology group & $\mathbf{n}$ & $\mathbf{M}$ & SD & Skew & Kurt \\
\hline Communication tools & 216 & 3.22 & .70 & .615 & -.228 \\
\hline Digital resources & 217 & 3.22 & .75 & .059 & .357 \\
\hline Digital tools & 217 & 2.36 & .68 & 1.027 & 1.416 \\
\hline Online learning tools & 216 & 2.35 & .72 & .835 & .828 \\
\hline
\end{tabular}

Legend: $\mathrm{n}=$ numerus, $\mathrm{M}=$ mean, $\mathrm{SD}=$ standard deviation, Skew = skewness, Kurt = kurtosis.

\subsection{Attitudes towards digital technologies as predictors of self-reported proficiency in using digital technologies}

The last research aim was to establish whether and how the participants' attitudes towards digital technologies in education predict their self-reported proficiency in using digital technologies. We used multiple regressions with a Stepwise method, and checked the possible effect on the dimensions of attitude for each digital technology group, as outlined in the following sections. We only present the dimensions, that based on Enter method, entered the model.

Communication tools: We first explored which dimensions of attitude towards digital technologies in education predict self-reported proficiency in using Communication tools. Communication tools are those used to communicate with different stakeholders in education, such as students, teachers, headteachers, parents and local and national communities. These tools include e-mails, blogs, forums, videoconferences and various social media which enable users to effectively communicate with others.

We calculated a multiple linear regression, to predict proficiency in using communication tools based on attitudes towards the use of digital technologies. Using the stepwise method, two predictors entered the model. We found a significant regression 
equation $(\mathrm{F}(2.185)=24.452, \mathrm{p}<.000)$, with an $\mathrm{R} 2$ of .457 . We thus discovered that attitudes towards Assessment and critical thinking significantly predict self-reported proficiency in using Communication tools $(\beta=.237, \mathrm{p}<.005)$, as do attitudes towards Empowering learners $(\beta=.273, \mathrm{p}<.005)$.

Table 3. Multiple regression results for Communication tools.

\begin{tabular}{|l|c|c|c|c|c|}
\hline \multicolumn{1}{|c|}{ Predictor } & B & SE & $\boldsymbol{\beta}$ & t & p \\
\hline Empowering learners & .403 & .121 & .273 & 3.333 & .001 \\
\hline Assessment and critical thinking & .306 & .106 & .237 & 2.895 & .004 \\
\hline
\end{tabular}

Note: Constant $=1.324, \mathrm{~F}(2.185)=24.452, \mathrm{p}<.000, \mathrm{R} 2=.457$.

Digital resources: We continued with the analysis of the role of attitudes towards digital technologies in education in predicting self-reported proficiency in using Digital resources. These resources include the various webpages containing content of interest and audio and video material that can be used in education.

We conducted a multiple linear regression, to predict self-reported proficiency in using Digital resources based on attitudes towards the use of Digital resources. Using the stepwise method, one predictor entered the model. We found a significant regression equation $(\mathrm{F}(1.186)=31.295, \mathrm{p}<.000)$, with an $\mathrm{R}^{2}$ of .144 . We also discovered that attitudes towards Empowering learners significantly predict self-reported proficiency in using Digital resources $(\beta=.379, \mathrm{p}<.001)$.

Table 4. Multiple regression results for Digital resources.

\begin{tabular}{|c|c|c|c|c|c|}
\hline Predictor & B & SE & $\boldsymbol{\beta}$ & t & p \\
\hline Empowering learners & .590 & .105 & .379 & 5.594 & .000 \\
\hline
\end{tabular}

Note: Constant $=1.591, \mathrm{~F}(1.186)=31.295, \mathrm{p}<.000, \mathrm{R} 2=.144$.

Digital tools: Next, we determined which dimensions of attitude towards using digital technologies predict self-reported proficiency in using Digital tools, or those intended to help create digital content, including digital educational resources.

We calculated a multiple linear regression to predict the use of Digital tools based on attitudes towards the use of Digital tools. Using the stepwise method, two predictors entered the model. We found a significant regression equation $(\mathrm{F}(2.185)=$ $43.323, \mathrm{p}<.000$ ), with an $\mathrm{R}^{2}$ of .391 . We then discovered that attitudes towards Assessment and critical thinking significantly predict Digital tools use $(\beta=208, \mathrm{p}<$ $.005)$, as do attitudes towards Empowering learners $(\beta=.414, \mathrm{p}<.001)$.

Table 5. Multiple regression results for Digital tools

\begin{tabular}{|l|c|c|c|c|c|}
\hline \multicolumn{1}{|c|}{ Predictor } & B & SE & $\boldsymbol{\beta}$ & t & p \\
\hline Empowering learners & .565 & .104 & .414 & 5.446 & .000 \\
\hline Assessment and critical thinking & .249 & .091 & .208 & 2.739 & .004 \\
\hline
\end{tabular}

Note: Constant $=.178, \mathrm{~F}(2.185)=43.323, \mathrm{p}<.000, \mathrm{R} 2=.391$.

Online learning tools: Our last analysis aimed to establish the role of different dimensions of attitude towards using digital technologies in education in self-reported 
proficiency in using Online learning tools. Online learning tools refer to online tools that prepare learners for collaborative processes, co-construction and co-creation of resources and knowledge.

We calculated a multiple linear regression, to predict self-reported proficiency in using Online learning tools based on various dimensions of attitude towards using digital technologies in education. Using the stepwise method, two predictors entered the model. We found a significant regression equation $(\mathrm{F}(2.185)=30.260, \mathrm{p}<.000)$, with an $\mathrm{R}^{2}$ of .246 . We then discovered that attitudes towards Assessment and critical thinking significantly predict self-reported proficiency in using online learning tools $(\beta=281, \mathrm{p}<.000)$, as do attitudes towards Empowering learners $(\beta=.471, \mathrm{p}<.05)$.

Table 6. Multiple regression results for Online learning tools.

\begin{tabular}{|l|c|c|c|c|c|}
\hline \multicolumn{1}{|c|}{ Predictor } & B & SE & $\boldsymbol{\beta}$ & t & p \\
\hline Empowering learners & .471 & .105 & .360 & 4.499 & .000 \\
\hline Assessment and critical thinking & .281 & .120 & .188 & 2.351 & .020 \\
\hline
\end{tabular}

Note: Constant $=.400, \mathrm{~F}(2,185)=30.260, \mathrm{p}<.000, \mathrm{R} 2=.246$.

Based on the multiple regression results, we conclude that two dimensions (out of four) of attitude towards using digital technologies in education predict self-reported proficiency in using various digital technologies: attitudes towards Assessment and critical thinking and attitudes towards Empowering learners. In addition, attitudes towards Empowering learners proved to be the strongest predictor of self-reported proficiency in using digital technologies. The highest predictive values of attitudes towards Empowering learners were obtained via self-reported proficiency in using Digital tools $(\beta=.414, \mathrm{p}<.001)$ and in using Digital resources $(\beta=.379, \mathrm{p}<.001)$.

\section{$7 \quad$ Discussion and Concluding Remarks}

This paper was built on the premise that attitudes towards using digital technologies in education are an important predictor of proficiency level in using digital tools for educational purposes [24]. The first research question aimed to determine Slovenian student teachers' attitudes towards using digital technologies. The results in general show that Slovenian student teachers predominantly have positive attitudes towards using digital technologies in education, which is in line with previous research $[19,24,25,26]$. Further analysis of the results shows that the student teachers hold mostly positive attitudes towards Teaching and learning, so they are in favour of using digital technologies to support teaching processes, student guidance and self-regulated learning. They are also positive about Facilitating learners' digital competence, referring to facilitating learners to become competent digital users. In addition, the student teachers are supportive of Empowering learners to use digital technologies, with the aim of differentiation and personalisation of educational processes via learners' active engagement based on accessibility and inclusion. The student teachers also report positive attitudes towards using digital tools for Assessment and developing critical 
thinking, including formative and summative assessments and targeted feedback for learners.

Following the second aim of the study, the student teachers were asked to assess their own proficiency in using digital technologies. The subsequent results show that student teachers report themselves as low- to basic-level users, where they use Communication tools and Digital resources on a basic level and predominantly do not use Digital or Online learning tools. These results are similar to the research findings reported by [23] who determined that student teachers assess themselves as competent users of basic ICT skills as opposed to advanced ICT skills and also didactic use of ICT. They also established [24] that teachers are mostly proficient users of search tools to look for information on the Internet, presentation programmes, office programmes and not so much in using digital tools in teaching practices. The results are also in line with [27] and thus confirm that student teachers under-use or are underproficient in using those digital technologies that offer the greatest added value to educational processes. These digital technologies (digital tools and online learning tools) enable teachers and students to not only use existing content but to design content according to their needs and available technologies, which enable them to collaboratively co-create and co-construct educational processes.

These outcomes should be considered in planning and delivering initial teacher education programmes in Slovenia. As already proposed in [39] digital technologies should be one of the key features of initial teacher curricula, within which student teachers gain theoretical knowledge and practical experience in using digital technologies. It should be noted that some research [40] shows that experience is an important factor in developing attitudes. In the context of developing positive attitudes towards using digital technologies in education, initial teacher programmes should develop a comprehensive approach, to fully integrate digital competence with a special focus on providing student teachers various and continuous experience in using digital technologies in the teaching process. We believe this initial teaching experience should be structured at three levels:

Special subjects (modules) aimed at gaining knowledge of digital technology use in education;

Subject-specialized and general digital technology integrated into all subjects (modules);

Practical experience, concisely organized by including experienced teachers as role models and aimed to construct digital competence.

Regarding the fact that teacher-specific digital competences in Slovenia are not subject to the regulations for ITE issued by top-level authority-the Ministry of education, science and sports, the integration of the digital competence in ITE is the responsibility of each higher education institution delivering ITE programmes. The integration of digital competence thus differs among universities, faculties and even programmes at the same faculty. However, being aware of the aim of ensuring that students gain adequate literacy and numeracy skills with the ability to use ICT during their compulsory education [41] along with the clear understanding of under-use of digital technologies by the student teachers (which is reflected in the Ministry call for project "Developing innovative methods of teaching and learning in ITE pro- 
grammes" proposals in this direction) the policy makers should make a step forward. Afterall, the Ministry has an important role in the final accreditation and reaccreditation [31] of each study programme, which provides the policy makers the opportunity (and the responsibility) to take a stand on the mandatory integration of digital competence in ITE programmes.

The fact is that student teachers need to gain the necessary technological competence to meet their students' needs during their initial teacher education [42]. Likewise, student teachers should acquire the skills and knowledge essential for ICT use in their initial teacher education and apply them during ITE period and in their professional life [43]. However, as stressed by [12] it is not sufficient to only introduce technology into ITE, teachers also need to acquire technological pedagogical content knowledge (TPCK), which enables them to use technology affectively. More precisely, student teachers should master technology knowledge, which includes basic and advanced technologies, content knowledge which refers to the subject matter to be learned and taught, and pedagogy knowledge which means the process and practice, or methods, of teaching and learning.

The last aim of the study was to determine if the student teachers' attitudes towards using digital technologies in education can predict their proficiency in using digital technologies in education. We determined that two dimensions of attitude, attitudes towards Assessment and critical thinking and attitudes towards Empowering learners, are the significant predictors of proficiency in using the digital technologies. The analysis shows that positive attitude reflects a higher level of proficiency in using technologies, so we can confirm the initial thesis of the study. The student teachers who recognize the value of digital technologies in enabling them and the students to develop critical thinking and provide targeted feedback to differentiate and personalize educational processes, reported higher levels of proficiency in using digital technologies. Thus, based on empirical evidence, we conclude that attitudes towards using digital technologies in education are an important factor in the level of proficiency in using digital technologies. These results are in line with other research findings [44, $45,46]$ which confirmed that there is a strong relationship between attitudes and use of digital technologies in education and that favourable attitudes strongly predict supportive digital technologies use.

\section{$8 \quad$ Study Limitations and Future Research Directions}

The possible generalizations based on this study are limited as the participants belong to the Slovenian educational environment. In the future, the reasonable direction seems to be to enlarge the size and the heterogeneity of the sample and also to include student teachers from other countries and put the study in the international context. However, the study and its results do outline some important issues that need to be addressed in the context of equipping student teachers with digital competences. Also, the findings suggest that further exhaustive research should also be done on the issue of teacher educators' digital competences-it is important how they value digital technologies in education and how proficient users they are. In the Slovenian context, 
research on in-service teachers' digital competence should also be carried out, also with regard to the level of education (preschool, primary school, secondary school), with regard to the subject area and with regard to the phase of career development (e.g. novice teachers vs. expert teachers). Also, the research could aim at surveying the present situation in supporting teachers on their way of empowering their digital competence in strong relation to all three dimensions: technology, pedagogy and content.

\section{Acknowledgement}

This work was supported by the Slovenian Ministry of Education, Science and Sports within the project "Innovative and flexible methods of teaching and learning in initial teacher education programmes."

\section{References}

[1] Johannesen, M., Øgrim, L., \& Giæver, T. H. (2014). Notion in Motion: Teachers' Digital Competence. Nordic Journal of Digital Literacy, 9(04), 300-312. https://doi.org/10.18261/ issn1891-943x-2014-04-05

[2] Buckingham, D. (2006). Defining digital literacy - What do young people need to know about digital media? Nordic Journal of Digital Literacy, 1(4), 263-277. https://doi.org/ 10.18261/issn1891-943x-2006-04-03

[3] ALT-J Research in Learning Technology, 18 (3), 207-220, https://doi.org/10.1080/0968 $\underline{7769.2010 .529108}$

[4] Erstad, O. (2006). A new direction? Education and Information Technology, 11(3), 415429. https://doi.org/10.1007/s10639-006-9008-2 .

[5] Aesaert, K., Vanderlinde, R., Tondeur, J., \& van Braak, J. (2013). The Content of Educational Technology Curricula: A Cross-Curricular State of the Art. Educational Technology Research and Development, 61(1), 131-151. https://doi.org/10.1007/s11423-012-9279-9

[6] Janssen, J., Stoyanov, S., Ferrari, A., Punie, Y., Pannekeet, K., \& Sloep, P. (2013). Experts' views on digital competence: Commonalities and differences. Computers \& Education, 68 , 473-481. https://doi.org/10.1016/j.compedu.2013.06.008.

[7] Sangrà, A. \& González-Sanmamed, A. (2010) The role of information and communication technologies in improving teaching and learning processes in primary and secondary schools, https://doi.org/10.1080/09687769.2010.529108

[8] Esteve-Mon, F. M., Llopis Angeles, A., Adel-Segura, J. (2020). Digital Competence and Computational Thinking of Student Teachers. International Journal of Emerging Technologies in Learning, 15 (2). https://doi.org/10.3991/ijet.v15i02.11588

[9] Čotar Konrad, S. (2018). Validacija vprašalnika digitalnih kompetenc študentv pedagoških študijskih programov. [Validation of digital competences for student teachers questionnaire.]. In Authors (Eds.), Oblikovanje inovativnih učnih okolij. [Constructing innovative learning environments] (pp.49-47). Koper: Založba Univerze na Primorskem.

[10] Redecker, C. (2017). European Framework for the Digital Competence of Educators: DigCompEdu. Luxenburg: Publications Office of the European Union, Luxembourg, https://doi.org/10.2760/159770 ,JRC107466. 
[11] Ala-Mutka, K. (2011) Mapping Digital Competence: Towards a Conceptual Understanding. Luxembourg: Publications Office of the European Union.

[12] Calvani, A., Cartelli, A., Fini, A., \& Ranieri, M. (2008). Models and Instruments for assessing Digital Competence at School. Journal of e-Learning and Knowledge Society, 4(3), 183-193.

[13] Mishra, P., Koehler, M. J. (2006). Technological Pedagogical Content Knowledge: A Framework for Teacher Knowledge. Teachers College Record, 108 (6), 1017-1054. https:// doi.org/10.1111/j.1467-9620.2006.00684.x

[14] Ng, W. (2012). Can we teach digital natives digital literacy? Computers \& Education, 59(3), 1065-1078. https://doi.org/10.1016/j.compedu.2012.04.016.

[15] European Commission (2007). Key competencies for lifelong learning: European Reference Framework, Office for Official Publications of the European Communities, Luxembourg. Retrieved from https://www.erasmusplus.org . uk/file/272/download .

[16] European Commission (2018). Proposal for a council recommendation on key competences for lifelong learning. Retrieved from https://ec.europa.eu/education/sites/education/ files/annex-recommendation-key-competences-lifelong-learning.pdf https://doi.org/10.11 11/ejed.12102

[17] Krumsvik, R. J. (2008). Situated learning and teacher's digital competence. Education and Information Technologies, 13 (4), 279-290. https://doi.org/10.1007/s10639-008-9069-5

[18] Krumsvik, R. J. (2014). Teacher Educators' Digital Competence. Scandinavian Journal of Educational Research, 58(3), 269-280. https://doi.org/10.1080/00313831.2012.726273

[19] Pettersson, F. (2018). On the issues of digital competence in educational contexts-a review of literature. Education and Information Technologies, 23 (3), 1005-1021. https://doi.org/10.1007/s10639-017-9649-3

[20] Gudmundsdottir, G. B., \& Hatlevik, O. E. (2018). Newly qualified teachers' professional digital competence: implications for teacher education. European Journal of Teacher Education, 41(2), 214-231. https://doi.org/10.1080/02619768.2017.1416085.

[21] Instefjord, E. J., \& Munthe, E. (2017). Educating digitally competent teachers: A study of integration of professional digital competence in teacher education. Teaching and Teacher Education, 67, 37-45. https://doi.org/10.1016/j.tate.2017.05.016.

[22] Yusop, F. D. (2015). A dataset of factors that influence preservice teachers' intentions to use Web 2.0 technologies in future teaching practices. British Journal of Educational Technology, 46(5), 1075-1080. https://doi.org/10.1111/bjet.12330.

[23] McGarr, O. \& McDonagh, A. (2019). Digital Competence in Teacher Education, Output 1 of the Erasmus+ funded Developing Student Teachers' Digital Competence (DICTE) project. https://dicte.oslomet.no/

[24] Aslan, A., \& Zhu, C. (2017). Investigating variables predicting Turkish pre-service teachers' integration of ICT into teaching practices. British Journal of Educational Technology, 48(2), 552-570. https://doi.org/10.1111/bjet.12437

[25] Cantabrana, J. L. L., Rodriguez, M. U., Cervera, M. G. (2019). Assessing Teacher Digital Competence: The Construction of an instrument for Measuring the Knowledge of PreService Teachers. Journal of new approaches in Educational Research, 8(1)73-78. https://doi.org/10.7821/naer.2019.1.370

[26] McGarr, O., \& Gavaldon, G. (2018). Exploring Spanish pre-service teachers' talk in relation to ICT: balancing different expectations between the university and practicum school. Technology, Pedagogy and Education, 27(2), 199-209. https://doi.org/10.1080/1475939x. 2018.1429950. 
[27] Sadaf, A., Newby, T. J., \& Ertmer, P. A. (2012). Exploring pre-service teachers' beliefs about using Web 2.0 technologies in K-12 classroom. Computers \& Education, 59(3), 937 945. https://doi.org/10.1016/j.compedu.2012.04.001

[28] Tondeur, J., van Braak, J., Siddiq, F., \& Scherer, R. (2016). Time for a new approach to prepare future teachers for educational technology use: Its meaning and measurement. Computers \& Education, 94, 134150. https://doi.org/10.1016/j.compedu.2015.11.009.

[29] Tondeur, J., Pareja Roblin, N., van Braak, J., Voogt, J., \& Prestridge, S. (2017). Preparing beginning teachers for technology integration in education: ready for take-off? Technology, Pedagogy and Education, 26(2), 157-177. https://doi.org/10.1080/1475939x.2016.11 $\underline{93556}$

[30] Tran, T., Phan, H. A., Van Le, H., Nguyen, H. T. (2020). Integration in Developing Competence for Pre-Service Mathematics Teachers. International Journal of Emerging Technologies in Learning, 15 (19), https://doi.org/10.3991/ijet.v15i14.14015.

[31] Gomez-Trigueros, S. (2020). Digital Teaching Competence and Space Competence with TPACK in Social Sciences. International Journal of Emerging Technologies in Learning, 15 (19). https://doi.org/10.3991/ijet.v15i19.14923

[32] European Commission/EACEA/Eurydice, 2019. Digital Education at School in Europe. Eurydice Report. Luxembourg: Publications Office of the European Union.

[33] Rules on training teachers and other professionals in primary education, (2015). Slovenian official Gazette (75/15).

[34] Rules on training teachers and other professionals in comprehensive education, (2015). Slovenian official Gazette (75/15).

[35] Rules on training teachers and other professionals in vocational education, (2012). Slovenian official Gazette (92/12).

[36] Standards for Accreditation of Initial Teacher Education programs, (2011). Retrieved from http://pisrs.si/Pis.web/pregledPredpisa?id=MERI41

[37] Slovenian Quality Assurance Agency for Higher Education, (2018). Retrieved from https://www.nakvis.si/wp-content/uploads/2019/05/NAKVIS_brosura_EN_web.pdf

[38] European Commission. (n. d.). European Credit Transfer an Accumulation System (ECTS). Retrieved from: https://ec.europa.eu/education/resources-and-tools/europeancredit-transfer-and-accumulation-system-ects_en https://doi.org/10.1080/03797720701840 $\underline{807}$

[39] Ministry of Education, Science and Sports of Slovenia. (2017). The analysis of the area of Innovative methods of Teaching and Learning in Initial Teacher Education Programmes.

[40] European Commission. (2014). Initial teacher education in Europe: an overview of policy issues. Brussels: European Commission.

[41] Štemberger, T. \& Kiswarday, V. (2018) Attitude towards inclusive education: the perspective of Slovenian preschool and primary school teachers, European Journal of Special Needs Education, 33 (1), 47-58 https://doi.org/10.1080/08856257.2017.1297573.

[42] OECD (2013). OECD skills outlook 2013: first results from the survey of adult skills. Retrieved from https://doi.org/10.1787/9789264204256-12-en

[43] Zhou, Q., Zhao, Y., Hu, J., Liu, Y., \& Xing, L. (2010). Pre-service chemistry teachers' attitude toward ICT in Xian. Procedia Social and Behavioral Sciences, 9, 1407-1414. https://doi.org/10.1016/j.sbspro.2010.12.342

[44] Yap1c1, I.U. \& Hevedanl1, M. (2012). International educational technology conference IETC2012. Preservice biology teachers' attitudes towards ICT using in biology teaching. Procedia Social and Behavioral Sciences, 64, 633-638. https://doi.org/10.1016/j.sbspro. $\underline{2012.11 .074}$ 
[45] Van Braak J., Tondeur J. \& Valcke, M. (2004). Explaining different types of computer use among primary school teachers. European Journal of Psychology of Education, 19 (4), 407-422. https://doi.org/10.1007/bf03173218

[46] Kreijns, K., van Acker, F., Vermeulen, M. \& van Buuren, H. (2013). What stimulates teachers to integrate ICT in their pedagogical practices? The use of digital learning materials in education. Computers in Human Behavior, 29 (1) 217-225. https://doi.org/10. 1016/j.chb.2012.08.008

[47] Sang, G., Valcke, M., van Braak, J., Tondeur, J. \& Zhu, C. (2011). Predicting ICT integration into classroom teaching in Chinese primary school: exploring the complex interplay of teacher-related variables. Journal of Computer Assisted Learning, 27 (2),160-172. https://doi.org/10.1111/j.1365-2729.2010.00383.x

[48] Aslan, A. \& Zhu, C. (2015). Pre-service teachers' perceptions of ICT integration in teacher education in Turkey. The Turkish Online Journal of Educational Technology, 14 (3), https://doi.org/10.1111/bjet.12437

\section{Authors}

Tina Štemberger is an associate professor of Educational Research at the University of Primorska, Faculty of Education, Cankarjeva 5, 6000, Koper. She is the Vicedean for Research and Doctoral Studies. The focus of her research are various dimensions of initial teacher education.

Sonja Čotar Konrad is an associate professor of Educational Psychology at the University of Primorska, Faculty of Education, Cankarjeva 5, 6000, Koper. She is a member of the professional group for implementing ICT in education, appointed by the Slovenian Ministry of Education, Science and Sports.

Article submitted 2021-03-15. Resubmitted 2021-04-14. Final acceptance 2021-04-17. Final version published as submitted by the authors. 